\title{
LA FORJA DE UNA ESTRELLA. CONFIGURACIÓN DEL REPERTORIO Y LA PERSONALIDAD ARTÍSTICA DE AMALIA MOLINA EN LA PRIMERA ETAPA DEL GÉNERO DE VARIEDADES
}

\author{
Ángeles Cruzado Rodríguez \\ Universidad Pablo de Olavide
}

Fecha de recepción: 01/11/2020

Fecha de aceptación: 07/03/2021

\section{Resumen}

Este artículo analiza las claves del triunfo de la cantaora, bailaora y cupletista sevillana Amalia Molina en los teatros de variedades desde su irrupción en la escena madrileña, en 1904, hasta el año 1910, coincidiendo con la que Álvaro Retana define como etapa inicial del género.

Palabras clave: Amalia Molina, variedades, cuplé, cante flamenco, baile flamenco, escuela bolera.

\section{THE FORGING OF A STAR. CONFIGURATION OF THE REPERTOIRE AND ARTISTIC PERSONALITY OF AMALIA MOLINA IN THE FIRST STAGE OF THE VARIETY GENRE}

\begin{abstract}
This paper analyses the keys to the triumph of the Sevillian cantaora, bailaora and cupletista Amalia Molina in the variety theatres from her arrival on the Madrid scene in 1904 until 1910, coinciding with what Álvaro Retana defines as the initial stage of the genre.
\end{abstract}

Keywords: Amalia Molina, Variety, Cuplé, Flamenco singing, Flamenco dancing, Bolero School.

\section{Sumario}

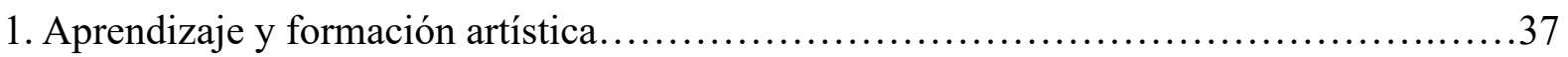

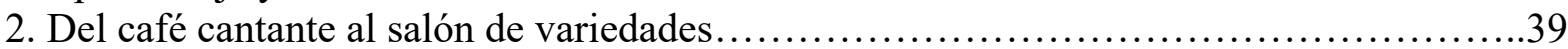

2.1. Cupletista y flamenca........................................................... 40

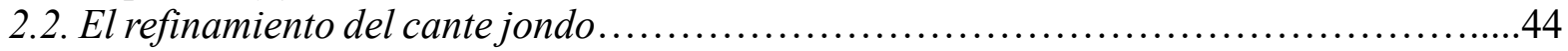

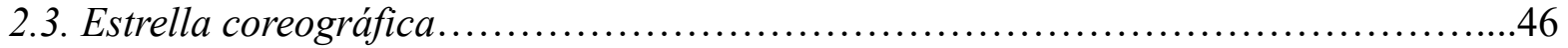

2.4. El género de los cantes y bailes regionales........................................... 48

2.5. Escenografía de las varietés.................................................49 
Enclaves. Revista de Literatura, Música y Artes Escénicas, n. . 1, 2021, pp. 36-55. e-ISSN 2792-7350

Ángeles Cruzado Rodríguez, «La forja de una estrella. Configuración del repertorio y la personalidad artística de Amalia Molina en la primera etapa del género de variedades», https://dx.doi.org/10.12795/enclaves.2021.i01.04

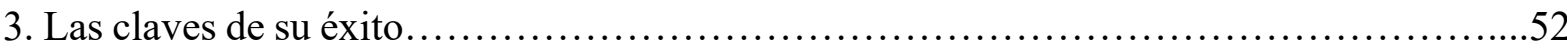

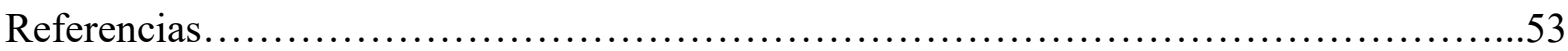

La cantaora, bailaora y cupletista Amalia Molina, ${ }^{1}$ que permaneció en activo hasta mediados de los años cincuenta del siglo XX, fue una de las grandes estrellas españolas de los escenarios de variedades. Nacida en Sevilla, donde aprendió desde pequeña el cante y el baile flamenco y de la Escuela Bolera, se trasladó a Madrid en 1904 en busca de nuevos horizontes profesionales. Debutó en el Salón de Actualidades, en el que trabajó durante trece meses consecutivos y se convirtió en una de las primeras figuras del recién inaugurado género de varietés. Dan testimonio de ello autores como Álvaro Retana, quien afirma que «en 1905, las cuatro "estrellas" más refulgentes del género ínfimo eran Pastora Imperio, la Fornarina, Chelito y Amalia Molina, y en torno a ellas brillaban [...] otros "asteroides" de menor cuantía» ("Historia" 43). ${ }^{2}$

Ese primer triunfo en Madrid supuso el despegue definitivo de una brillante y dilatada carrera, que transcurrió por teatros y salones de toda España, y adquirió dimensión internacional, con prolongadas giras por Europa, el norte de África y, principalmente, por América. Una trayectoria así, que va mucho más allá de un simple éxito pasajero, no puede deberse al azar, máxime en un contexto en el que la juventud y la belleza estaban entre las cualidades más valoradas en las artistas. Nos proponemos, pues, desentrañar y analizar las claves que llevaron a Amalia Molina a alcanzar la gloria y a mantenerse durante años en lo más alto del escalafón. Ante la imposibilidad de abordar su medio siglo de trabajo sobre las tablas, nos centraremos en la que Álvaro Retana definió como edad antigua de las variedades, que coincide con la primera década del siglo XX ("Historia" 43).

\section{Aprendizaje y formación artística}

Amalia Molina nació en Sevilla el 28 de enero de $1885 .^{3}$ Aunque en su familia no existían artistas profesionales, se crio en un ambiente muy popular, en el que el flamenco y el folclore formaban parte de su día a día. Así lo reconocía la propia artista en una entrevista concedida en 1944 a Gil Gómez Bajuelo: «Mis ojillos vieron la lu primera en la casa más flamenca de Seviya, el Corral del Cristo, de la calle Pedro Migué» (4). Según su biógrafo, García Carraffa, a ese lugar lo hicieron «célebre las fiestas y los bailes que en él se celebraban los domingos y a los que concurría un admirable, supremo y delicioso mujerío» (15).

Allí comenzó Amalia un aprendizaje vivencial, inconsciente, en el que tuvo múltiples maestras, y entre ellas una muy especial:

\footnotetext{
${ }^{1}$ Recientemente ha visto la luz la biografía Amalia Molina (1885-1956). Memoria de una universal artista sevillana (Cruzado 2020), que realiza un seguimiento de la carrera artística de su protagonista a partir de un trabajo de investigación hemerográfica. A diferencia de la citada obra, este artículo no se queda en la crónica descriptiva, sino que va un paso más allá. Aborda con mayor profundidad el contexto y las influencias recibidas por Amalia Molina tras su llegada a Madrid para abrirse camino en el género de las variedades, y analiza el modo en que empezó a construir su repertorio y a crearse un estilo propio, al que permanecería fiel durante toda su vida.

${ }^{2}$ En 1912, Amalia Molina seguía ocupando un puesto destacado en los rankings de estrellas de variedades, como en el que recoge Colirón en la revista Madrid Cómico: «De cuantas "estrellas" de "varietés" pisan las tablas, merecen únicamente especial mención, según mi humilde modo de pensar, las señoritas La Goya, Amalia Molina, Pastora Imperio, Consuelo Bello (Fornarina) y la Argentina» (12).

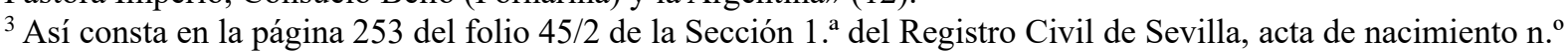
102.
} 
Enclaves. Revista de Literatura, Música y Artes Escénicas, n. ${ }^{\circ}$ 1, 2021, pp. 36-55. e-ISSN 2792-7350

Ángeles Cruzado Rodríguez, «La forja de una estrella. Configuración del repertorio y la personalidad artística de Amalia Molina en la primera etapa del género de variedades», https://dx.doi.org/10.12795/enclaves.2021.i01.04

— ¿Y cómo se despertó en usted esa afición?

- De ver bailá a las mositas del barrio, y sobre too de vé bailá a mi madre, que lo hasía mu divinamente. A los siete años ya bailaba yo las sevillanas solo de habérselas visto bailá a ella. (García Carraffa 17)

En los años de su infancia asistió con asiduidad a las fiestas que tenían lugar cada semana en los corrales sevillanos -en el del Cristo, en el de Enciso...-, así como en la época del carnaval o las Cruces de Mayo. A decir de García Carraffa, la niña «no solo bailaba ya primorosamente; cantaba también con excelente estilo las sevillanas corraleras y otras canciones andaluzas»» (20). Además, siguiendo el ejemplo de su madre, ${ }^{4}$ a los ocho años cantó por primera vez saetas al paso de las procesiones de Semana Santa (21).

Dadas las buenas dotes artísticas de la pequeña así como su gran afición, su familia le buscó un maestro con el que continuar su aprendizaje de un modo más formal: «en vista de lo apañá que yo era pa too lo flamenco, me fui a la academia de Joselito Castillo, el bailarín famoso, y a él me encomendé y él me enseñó a bailá» (Carretero Novillo 16). Continuó sus estudios con Ángel Pericet, gran maestro sevillano de la Escuela Bolera, que la hizo debutar en 1895 en el Teatro de la Alhambra de Madrid junto a una troupe infantil en la que también figuraba su sobrina Carmen Díaz Molina. ${ }^{5}$ El repertorio de la compañía incluía sevillanas, manchegas, malagueñas, peteneras, el baile inglés y el olé andaluz, entre otras danzas. Las crónicas periodísticas destacan la labor de la pequeña Amalia, que hizo «primores» ejecutando el Vito (Fray-Cirilo, "Teatro" a 2) y «cantó con mucho estilo algunas coplas de malagueñas» (Fray-Cirilo, "Teatro" b 2). A su regreso a Sevilla, continuó su formación con otro gran referente de la Escuela Bolera, el maestro José Otero, que décadas más tarde aún la recordaba como una de sus alumnas más sobresalientes: «para bailar con arreglo a escuela, ninguna artista como esa pimienta, que rabia y pica, llamada Amalia Molina. En eso no le gana a ella nadie» (Muñoz San Román 6).

A ese aprendizaje vivencial y al estudio con diferentes maestros hay que sumar la experiencia profesional en distintos cafés cantantes de Sevilla, tales como el Suizo, el Novedades o el Salón Filarmónico-Oriente. En el primero de ellos, durante la temporada de primavera de 1898, formó parte de un cuadro de bailes españoles y franceses dirigido por el maestro Bermúdez, en el que coincidió con bailarinas como Magdalena Bermúdez, Carmen Álvarez, Julia Domínguez o Isabel Fernández. ${ }^{6}$ En 1902 se integró en el cuadro de baile bolero del Café Concierto Novedades, junto a la Loleta, la Bermúdez, Eloísa Díaz y Carmen Díaz, bajo la dirección del maestro Enrique Sánchez. El elenco flamenco de ese local estaba formado por «La Macarrona, La Malena, La Sordilla, La Melliza, La Roteña, La Trini, Rita Ortega, Enriqueta la Macaca, La Junquera, El Tiznao, y el guitarrista El Ecijano» (Blas Vega 71), además de don Antonio Chacón, como figura principal. En 1903 fue contratada para formar

\footnotetext{
${ }^{4}$ Así lo refiere su biógrafo, a partir del testimonio de la propia artista. No obstante, esta ofrece algunos datos sobre su genealogía familiar que no concuerdan con los documentos oficiales, lo cual nos lleva a plantear la duda de si ese primer referente artístico se correspondía realmente con su madre (Teresa Jiménez, natural de Antella, Valencia) o con alguna de sus hermanas mayores, fruto del primer matrimonio de su padre, a las que Amalia nunca menciona.

${ }^{5}$ Completaban el elenco Pastora Sánchez, Manuel Martínez y Carmen Álvarez como primera bailarina (El Liberal, “Entre bastidores”a 4). El grupo pasó después al Teatro Príncipe Alfonso de Madrid y también actuó en otras ciudades, como Segovia, Palencia, Burgos o Logroño.

${ }^{6}$ Información contenida en el cartel del Café Suizo, del 15 de mayo de 1898. Archivo de prensa de Sevilla de José Luis Ortiz Nuevo.
} 
Enclaves. Revista de Literatura, Música y Artes Escénicas, n. ${ }^{\circ}$ 1, 2021, pp. 36-55. e-ISSN 2792-7350

Ángeles Cruzado Rodríguez, «La forja de una estrella. Configuración del

repertorio y la personalidad artística de Amalia Molina en la primera etapa del género de variedades», https://dx.doi.org/10.12795/enclaves.2021.i01.04

parte del cuadro bolero del Filarmónico, dirigido por el maestro Pericet. En este salón compartió cartel con Rita Ortega, Pepa de Oro, Antonio Ramírez, Juan Ríos y Juan Ganduya, Habichuela, entre otros artistas (Blas Vega 55). Es indudable que el contacto diario con esas grandes figuras del cante y del baile también hubo de dejar un poso importante en la joven Amalia. De hecho, cuando años más tarde le preguntó El Caballero Audaz «¿Cuál ha sido su maestro de canto flamenco?», ella no dudó en responder: «¡Chacón!... Es el que más me gusta. Yo lloro oyendo cantá a Chacón... Juan Breva también se traía lo suyo» (Carretero Novillo 17).

\section{Del café cantante al salón de variedades}

[...] llegó al café de Novedades una cupletista de las que entonces actuaban con éxito. Cantaba los tangos de Venus Salón y de El género ínfimo, y otros números. Bailaba poco, solo para defenderse. Sin embargo, iba contratada por 20 pesetas diarias.

Amalia concibió entonces el propósito de aprender aquel repertorio, puesto que se encontraba con sobradas facultades para ello.

A este fin, obtuvo del pianista del establecimiento, «Cieguecito Reyes», copias de la música y de la letra de los tangos, y para aprenderlos iba una hora antes al café y ensayaba con el pianista. Una vez impuesta en el nuevo género que se proponía cultivar [...], decidió venir a Madrid. (García Carraffa 27)

El acicate que impulsó a Amalia Molina, en 1904, a dejarlo todo y emprender una nueva vida en Madrid fue el conocimiento de ese nuevo género artístico, en boga en la capital desde los albores del siglo $\mathrm{XX}$, que ofrecía mejores perspectivas económicas y profesionales que el flamenco y el bolero. En esos años ya se empezaba a sentir la decadencia de los cafés cantantes. A la mala fama que se asociaba a dichos locales -por su vinculación con la prostitución, las trifulcas y las gentes de mal vivir- había que sumar la campaña antiflamenquista emprendida por intelectuales y escritores, así como las reformas legislativas cada vez más restrictivas, que culminaron con la orden de cierre de los cafés cantantes madrileños, por orden gubernativa, en 1908. Ante esta situación, muchos flamencos -sobre todo, mujeres- encontraron en los salones y teatros de variedades un refugio y un nuevo ámbito en el que desarrollarse artísticamente.

Las varietés llegaron a nuestro país, desde Francia, a finales del siglo XIX y alcanzaron un desarrollo considerable en torno al año 1900. Como su propio nombre indica, dichos espectáculos incluían números de muy diverso tipo: canciones, bailes, atracciones circenses, ilusionismo, humor, acrobacias, etcétera. En ese contexto, adquirió especial protagonismo el cuplé.

Definido por la RAE como «canción corta y ligera, que se canta en teatros y otros locales de espectáculo», el término aglutina una larga tradición de canción popular y teatro lírico español, que se remonta hasta la tonadilla escénica dieciochesca, pasando después por la zarzuela y el género chico, y que tomó carta de naturaleza en los escenarios de varietés como canción independiente, permeable a las influencias de otros estilos artísticos y musicales:

El género ínfimo ${ }^{7}$ no es más que un hijo legítimo del género chico, la explotación comercial de sus facetas más espectaculares, tanto verbales (la procacidad tan cacareada) como vocales o

\footnotetext{
${ }^{7}$ En su época inicial, que coincide con la primera década del siglo XX, el de variedades también fue conocido como «género ínfimo», denominación tomada del título de la zarzuela homónima de los hermanos Álvarez Quintero, con música de Valverde y Barrera, estrenada en 1901 en el Teatro Apolo de Madrid: «[Los autores] pretendían burlarse de las nuevas costumbres del teatro lírico y de la moda invasora de los cabarés y los cafésconciertos. De hecho, más que denunciar, la obra utilizaba ciertas prácticas "culturales" y basaba su éxito sobre
} 
Enclaves. Revista de Literatura, Música y Artes Escénicas, n. ${ }^{\circ}$ 1, 2021, pp. 36-55. e-ISSN 2792-7350

Ángeles Cruzado Rodríguez, «La forja de una estrella. Configuración del repertorio y la personalidad artística de Amalia Molina en la primera etapa del género de variedades», https://dx.doi.org/10.12795/enclaves.2021.i01.04

gestuales (la exhibición del cuerpo femenino). El naciente cuplé corresponde a la incipiente emancipación del componente vocal, al nacimiento de la canción como espectáculo en sí y las variedades obedecen al proceso estructurador (lo que se refiere a los públicos, los establecimientos, el aspecto comercial del fenómeno). (Salaün, El cuplé 36-37)

Una de las primeras cancionistas de importación que pisaron los escenarios españoles fue la alemana Augusta Bergès, que en 1893 interpretó en el Teatro Barbieri de Madrid la polca italiana «La pulga»y, mientras buscaba entre sus ropas el diminuto insecto, mostró a los espectadores buena parte de su anatomía. El director del Salón de Actualidades, Eduardo Montesinos, creó una versión española del tema, que fue estrenada por la cupletista Pilar Cohen, ataviada con un sugerente salto de cama. Otras artistas, como Julita Fons o la Bella Chelito, también se sumaron a esa moda de la sicalipsis, ${ }^{8}$ que marcó la etapa inicial del género (Salaün, "El género ínfimo" 155-156).

El nacimiento de las variedades respondió a una necesidad de las clases populares urbanas, que demandaban nuevos espacios de socialización y un tipo de divertimento que no requiriese un elevado esfuerzo intelectual. Recién inaugurado el siglo XX, empezaron a surgir en Madrid salones especializados en ese nuevo tipo de espectáculos, como el Rouge, el Bleu o el Teatro Japonés, y la moda no tardó en extenderse a otras ciudades españolas. Ni que decir tiene que a ellos acudía un público eminentemente masculino, que disfrutaba de la función con una actitud a veces violenta, bulliciosa y grosera, que en más de una ocasión provocó la intervención de las fuerzas del orden.

Para ir construyendo sus números, las primeras cupletistas españolas, además de recurrir a la adaptación de canciones extranjeras, acudieron al vasto repertorio del género chico, que con el nuevo siglo también se había adherido a la corriente sicalíptica, e incluía canciones picantes, llenas de dobles sentidos, que a veces incluso ofrecían a las artistas una excusa perfecta para quitarse la ropa.

Por citar un ejemplo, la tiple María López Martínez hizo muy popular el «Tango del morrongo», de la zarzuela Enseñanza Libre (1901) -con libreto de Guillermo Perrín y Miguel de Palacios, y música de Gerónimo Giménez-, que se estrenó en el Teatro Eslava de Madrid. La letra hablaba sobre un gatito que se estiraba y se encogía de gusto, cuando la artista lo acariciaba, posado sobre su falda. No obstante, a pesar de su aparente inocencia, la canción despertó las críticas de ciertos moralistas, como un redactor de La Correspondencia Militar, que señalaba «las dos grandes novedades que nos deja el 1901: La Pulga y el tango del Morrongo, que hace votar [sic] a muchos caballeros en sus butacas y debilita a no pocos adolescentes de una manera lamentable» (R. M. 1).

Posteriormente, autores de prestigio, en muchos casos procedentes del mundo del teatro, como los hermanos Álvarez Quintero, empezarían a poner su creatividad al servicio de las más famosas cupletistas, que buscarían diferenciarse, con la conformación de un repertorio exclusivo.

\subsection{Cupletista y flamenca}

Amalia Molina irrumpió en el panorama teatral madrileño en 1904. Criada en un contexto humilde, y huérfana de padre y madre desde los dieciséis años, buscaba en los salones de

la plástica (generosa) de las intérpretes femeninas (tiples y vicetiples) y sobre la canción en plena mutación (el cuplé)». (Salaün, "El género ínfimo" 147)

${ }^{8}$ Este término es definido por la RAE como «malicia sexual, picardía erótica». 
Enclaves. Revista de Literatura, Música y Artes Escénicas, n. ${ }^{\circ}$ 1, 2021, pp. 36-55. e-ISSN 2792-7350

Ángeles Cruzado Rodríguez, «La forja de una estrella. Configuración del repertorio y la personalidad artística de Amalia Molina en la primera etapa del género de variedades», https://dx.doi.org/10.12795/enclaves.2021.i01.04

variedades un futuro mejor, dado que su trabajo en los cafés cantantes de Sevilla apenas le daba para sobrevivir. ${ }^{9}$ No se diferenciaba mucho, por tanto, de ese nutrido grupo de chicas jóvenes procedentes de las clases más populares,${ }^{10}$ muchas de ellas con escasa instrucción y formación artística, que veían en las tablas una buena manera de salir de la pobreza (Salaün, "Las mujeres" 67), si no fuese por sus excelentes dotes artísticas, que la llevaron a convertirse en una de las primeras figuras del género.

En sus inicios se sumó a la moda del cuplé e incluyó en su primer repertorio algunos de esos cantables extraídos de zarzuelas, que habían sido popularizados por tiples como Isabelita Bru con un alto grado de picardía y erotismo. Dos de sus números más emblemáticos de aquella época fueron el «Tango del morrongo», de la zarzuela Enseñanza libre, que incluso registró para la casa Odeón, ${ }^{11}$ y el «Tango de los lunares», de El género infimo, con su popular estribillo: «yo tengo dos lunares / uno juntito a la boca / y el otro donde tú sabes».

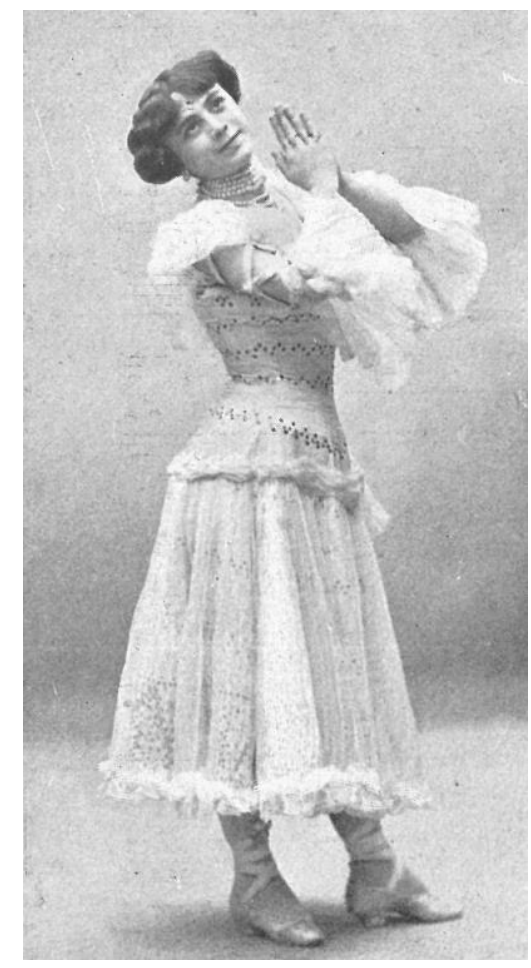

Imagen 1. Amalia Molina en el «Tango de los lunares» (El Teatro 7).

\footnotetext{
${ }^{9}$ A su llegada a la capital, todo su patrimonio ascendía a siete pesetas, un «mantón blanco de Manila, una falda de seda con volante de color rosa y un sombrero cordobés blanco» (García Carraffa 28).

${ }^{10}$ De hecho, en las primeras décadas del siglo XX llegó a producirse una auténtica inflación de aspirantes a cupletistas, atraídas por la perspectiva del dinero fácil: «El "coupletismo" es una enfermedad grave que padecemos ya con carácter endémico. [...] tomamos café sin adoptar precauciones, que consideramos ociosas en un establecimiento servido por camareras, y de pronto una nos amarga la digestión revelándonos el secreto terrible: quiere ser cupletista, y así es preciso huir de las porteras, fámulas, camareras, modistillas y demás muchachas de buen palmito, a las cuales el espejo dice unas palabras misteriosas... Sin necesidad de que hablen los espejos, es cosa olvidada de puro sabida, que algunas artistas de "varietés" ganan a diario cantidades fabulosas» (Larios de Medrano 1).

${ }^{11}$ En 1910 se anuncian en El Diario de Ciudad de México varios discos dobles impresionados por Amalia Molina, que contienen los tientos gitanos «Mari Gloria», el tango «El morrongo», el «Tango del mantón», el cuplé «La Primavera», las canciones «Achares» $\mathrm{y}$ «Azahares», «Granadinas» y «Marianas» (“Agencia” 22).
} 
Enclaves. Revista de Literatura, Música y Artes Escénicas, n. ${ }^{\circ}$ 1, 2021, pp. 36-55. e-ISSN 2792-7350

Ángeles Cruzado Rodríguez, «La forja de una estrella. Configuración del repertorio y la personalidad artística de Amalia Molina en la primera etapa del género de variedades», https://dx.doi.org/10.12795/enclaves.2021.i01.04

Sin embargo, Amalia buscó diferenciarse, valiéndose para ello de los conocimientos y aptitudes artísticas que había cultivado desde su infancia, y llevó la canción al terreno flamenco, algo en lo que puede considerarse pionera. Desde su debut en el Salón de Actualidades, cosechaba cada noche «grandes ovaciones, especialmente en el célebre tango de los lunares, que repite infinidad de veces, así como el Morrongo, que no se ha cantado mejor en Madrid» (El Día 2). El «Tango del caracolillo» o el «Tango del café», de la revista Certamen nacional, ${ }^{12}$ y el zapateado «El día que yo nací», del juguete cómico-lírico Caramelo ${ }^{13}$, también formaron parte de ese primer repertorio tomado del género chico. A partir de la letra creada por los Álvarez Quintero para los tientos de El género ínfimo:

El maestro Badía escribió para Amalia otro tango no menos popular:

«Si porque canto y bailo flamenco

dice la gente que me condeno

será muy fácil que cuando muera

no vaya al cielo.

Llamaré a San Pedro,

le enseñaré los lunares...

¡me coge y me mete adentro!» (Retana, "La novela" 8).

Esta pieza, titulada «Los lunares de San Pedro», fue durante años uno de los números que más le solicitaba el público. En sus confesiones a García Carraffa, la artista cuenta cómo lo llevó a su terreno e hizo de él una auténtica creación:

Al cantar el estribillo «Llamaré a San Pedro», se le ocurrió hacer unos pasos de flamenco muy gitanos, en los que los rizos y las peinetas bailaban con la artista, y el público estalló en una ovación delirante.

—Si viera usté qué divinamente me salió aquello —nos decía Amalia—. No ya mi voz; mi falda, mi mantonsillo, mi pelo, mis peinetas, todo lo que llevaba ensima, llamaba al mismo tiempo a San Pedro. (33)

En su número del mes agosto de 1904 la revista El Teatro ${ }^{14}$ dedicó un amplio reportaje fotográfico a «la coupletista de moda», en el que se la podía ver interpretando varios de sus números, entre ellos el famoso «Tango de los lunares», con un vestuario y unas poses que nada tienen de sicalíptico. El artículo destacaba sus excelentes cualidades y le auguraba un prometedor futuro:

Voz agradable, intuición artística, dicción correcta y una desenvoltura que para sí quisieran muchas tiples que alardean de cómicas; todo esto y algo más se reúne en Amalia Molina, una de las mejores cupletistas hoy, una buena tiple cómica algún día (5).

Consciente su gran potencial, la empresa del Salón de Actualidades le ofreció los medios para ir ampliando su repertorio, con canciones escritas por distintos maestros, que ella convirtió en creaciones personales. De esa época son «Achares»y «Mi serrano», ambas con letra de Eduardo Montesinos y música de Pedro Badía; «La pena pena», escrita por José Cánovas

\footnotetext{
12 Obra de 1888, con libreto de Guillermo Perrín y Miguel de Palacios, y música de Manuel Nieto.

${ }_{13}$ Obra estrenada en 1884, con libreto de Javier de Burgos, y música de Federico Chueca y Joaquín Valverde.

${ }^{14}$ En las páginas de la revista El Teatro aparecen músicos, actores y actrices de prestigio, españoles y extranjeros, como Fernando Mendoza, María Guerrero, Elena Salvador, Gerónimo Giménez o Richard Wagner.
} 
Enclaves. Revista de Literatura, Música y Artes Escénicas, n. ${ }^{\circ}$ 1, 2021, pp. 36-55. e-ISSN 2792-7350

Ángeles Cruzado Rodríguez, «La forja de una estrella. Configuración del

repertorio y la personalidad artística de Amalia Molina en la primera etapa del género de variedades», https://dx.doi.org/10.12795/enclaves.2021.i01.04

Vallejo, con partitura de Arturo Lapuerta; «Mi azotea», de Montesinos y Lapuerta; o «El columpio» y el tango coreado «El cocotero», con letra y música de Enrique García Álvarez (García Carraffa 33-34). Esta búsqueda de la diferenciación y de la exclusividad se convertiría en una constante a lo largo de su carrera:

Amalia cuida también mucho de mantener su personalidad artística. No canta ningún número que no sea creación suya y que no haya pasado por el tamiz de su hondo sentido artístico.

Además, exige a todos los autores una carta en la que hacen constar que mientras ella actúa en una población, no puede otra cancionista o bailarina cantar o bailar las mismas composiciones musicales en ninguno de los teatros de la localidad.

También goza de la exclusiva para impresionar sus creaciones en los gramófonos. (García Carraffa 92-93)

En aquellos años también estrenó la canción «El niño de las escobas», en la que imitaba a un popular tipo sevillano; el bailable cantado «La chiclanera», del maestro Segura; el pasacalle «Viva mi tierra», con letra de Montesinos; el pregón andaluz «Clavelitos», ${ }^{15}$ de José Juan Cadenas con música de Quinito Valverde; la canción «El hoyito», el cuplé «La sultana», el «Tango de la Esperanza» o unos «tientos gitanos titulados "la Molina", cuya música muy original y muy delicada por cierto, débese al distinguido maestro don Luis López» (El Popular, "Espectáculos" 1).

Estas canciones y cuplés, interpretados por la artista de un modo tan personal, no tardaron en calar en el público, que los hizo suyos:

Quien más, quien menos, marcha por nuestras calles tarareando los saladísimos «couplets» que la simpática artista nos coloca todas las noches [...].

Y ahora no vendrían mal, entre estos párrafos, unas cuantas observaciones sobre la influencia que el «couplet» ejerce en el público. Claro está que para ello, partiríamos de la base de «según quien los cantase».

[...] Unos «couplets», aun muy ingeniosos y oportunos, cantados por una artista, ayuna de belleza, de arte y de picardía, mueren sin encontrar eco en la opinión.

[...] Así, pues, los «couplets» que la Amalia Molina nos sirve, han de convivir con nosotros, por mucho tiempo, porque yo creo que la gracia, la gentileza y la hermosura de la Amalia Molina, son de las que no se olvidan tan fácilmente. (El Adelanto, “¡Nos vamos!” 1)

Las crónicas de la época coinciden en destacar la gracia, el arte y el sentimiento con que dice sus canciones. No necesita recurrir a la picardía, el erotismo y los dobles sentidos para conquistar al público, «pues su trabajo es por sí solo sugestivo y arranca a los morenos haciéndose aplaudir todo cuanto quiere, sin emplear [...] frases ni ademanes propios de la moderna sicalipsis» (Fray-Cine 7, "Amalia" 2).

$\mathrm{Su}$ originalidad no se basaba únicamente en la elección de un repertorio nuevo y exclusivo, sino también en la manera de interpretarlo y presentarlo, con un marcado carácter andaluz y flamenco, que estaba presente en los giros de su voz, en los pasos de baile que intercalaba, en el vestuario y en la actitud, así como en la inspiración de los autores que escribían y componían para ella, muchos de los cuales eran de origen andaluz. Es el caso de Eduardo Montesinos o Gerónimo Giménez, ya mencionados, y también de Manuel Font de Anta, Gaspar Vivas o José Padilla, con los que también trabajó a lo largo de su carrera.

\footnotetext{
${ }^{15}$ Esta canción ya había sido cantada por Consuelo Vello Cano, la Fornarina.
} 
Enclaves. Revista de Literatura, Música y Artes Escénicas, n. . 1, 2021, pp. 36-55. e-ISSN 2792-7350

Ángeles Cruzado Rodríguez, «La forja de una estrella. Configuración del

repertorio y la personalidad artística de Amalia Molina en la primera etapa del género de variedades», https://dx.doi.org/10.12795/enclaves.2021.i01.04

\subsection{El refinamiento del cante jondo}

Inés María Luna López destaca las influencias recíprocas que se produjeron entre el cuplé y el flamenco a principios del siglo XX:

Estos años constituyen una época muy negativa para el flamenco, que ha vivido un periodo de esplendor en los tiempos del café cantante. Muchos cantaores y cantaoras interpretan dicho género artístico y actúan en los espectáculos de variedades [...].

Como un camino alternativo, el flamenco encuentra un refugio en el cuplé. Sucede, además, que músicos, dramaturgos y letristas realizan, en su búsqueda de cultura nacional, una gran labor de conservación y divulgación de las canciones regionales. [...] De esta manera, el flamenco entra en los teatros para ser interpretado con la orquesta (40-41).

En esa etapa de evolución y efervescencia creativa, Amalia Molina puso su talento y versatilidad al servicio del nuevo género que se estaba gestando. Sin embargo, aunque alcanzó gran fama con las canciones o cuplés aflamencados, nunca dejó de lado el repertorio propiamente flamenco, que siguió siendo su seña de identidad.

En la prueba que le realizaron Eduardo Montesinos y Ramiro Cebrián -director artístico y empresario del Salón de Actualidades- antes de contratarla, interpretó varios cuplés, tangos y soleares acompañada al piano por el maestro Badía, con las partituras que le había proporcionado el cieguecito Reyes en el Café Novedades de Sevilla (García Carraffa 31). Como señala Inés Luna, «en los albores del siglo XX comienza la orquestación de los cantes flamencos» (45) y Amalia Molina mostró abiertamente su preferencia por este tipo de instrumentación: «A mí el flamenco me gusta cantarlo al piano... ¡Qué sé yo!... A la guitarra me huele a aguardiente y en orquesta a champagne» (Carretero Novillo 17). Da testimonio de ello su extensa discografía, en la que encontramos interesantes ejemplos de cantes por soleares, bulerías, fandangos de Huelva, malagueñas, fandangos de Lucena, sevillanas, tangos, saetas o pregones, con letras tradicionales y acompañamiento sinfónico.

Mas sus innovaciones no se limitaron a lo meramente musical. En un momento de profundo rechazo a la «imagen del "flamenquismo" que emanó de los ambientes que rodeaban locales y espectáculos jondos, calificados tanto por los intelectuales como por la sociedad civil como lugares de vida marginal, refugio de borrachos, prostitutas, arena de peleas y procacidad» (Cruces 254), Amalia consiguió elevar la categoría del género, haciendo de él un arte refinado, de buen gusto, capaz de satisfacer a los paladares más exigentes:

Y esas canciones eran expresadas por Amalia Molina [...] como nunca las habíamos oído. Despojado del flamenquismo ronco del tablado, que envuelve en una sombra de vicio el cuadro. Despojado de todo aquello que a la delicadeza más exigente ofender pudiera, el alma del pueblo ora transparentada a través de la ejecución admirable de una artista de corazón, de una genialísima artista, que ha sabido elevar, desde las mesas de los cafés cantantes a los escenarios en que las más depuradas exquisiteces se exhiben, el desgarrado, brioso, sentido, bellísimo cante flamenco. Milagro de diosa o de hechicera. (El Cantábrico, "Amalia" 1)

Para lograrlo se valió de su «bonita y timbrada voz» (Fray-Cine, "Por los cines" 2), de «un estilo que para sí quisieran tantas y tantos cantaores que se desgañitan por esos mundos de Dios» (Las Provincias 2), y de una elevada dosis de sentimiento y verdad. «No canta por salir del paso ni por cumplir un compromiso; cuando canta lo hace con el corazón» (La Opinión 2). Amalia teatralizó el cante flamenco y lo dijo con su cuerpo entero: 
Enclaves. Revista de Literatura, Música y Artes Escénicas, n. . 1, 2021, pp. 36-55. e-ISSN 2792-7350

Ángeles Cruzado Rodríguez, «La forja de una estrella. Configuración del repertorio y la personalidad artística de Amalia Molina en la primera etapa del género de variedades», https://dx.doi.org/10.12795/enclaves.2021.i01.04

Todo en ella es armónico, igual, es el prototipo del cante flamenco. Al mirarla se convence uno que esa mujer nació para cantar: cantan sus ojos malignos y gachones; cantan sus dedos ágiles, cubiertos de joyas; canta su pelo negro como la noche; y en las orejas, chiquitinas y blancas, los brillantes cegadores cantan triunfales, heridos por la luz, un himno al amor y a la belleza. (Cuevas 2)

En esos años deleitó a los públicos españoles y latinoamericanos ${ }^{16}$ con sus tientos, tangos, soleares, granaínas, malagueñas, sevillanas, peteneras, marianas, farrucas y garrotines, que unas veces interpretó con orquesta y otras, a la manera tradicional. Una de sus más fieles acompañantes fue la guitarrista Adela Cubas, con quien trabajó en diversas ocasiones. ${ }^{17}$ Merecen especial mención sus actuaciones en tierras levantinas durante el año 1908, en las que ambas demostraron gran compenetración artística. ${ }^{18}$ Según distintos testimonios, uno de sus cantes más emblemáticos eran las malagueñas:

Amalia Molina, verdadera estrella en su género, acompañada con guitarra por la Cubas, [...] cantó unas malagueñas deliciosas, modelo de sentimiento y de buen gusto, que el selecto auditorio saboreó con deleite. Ante los insistentes aplausos la joven y bella sevillana cantó unos tientos que le valieron una nueva ovación. ( $A B C$, "La fiesta" 14)

[...] en su trabajo tiene una gran especialidad que consiste en cantarse unas malagueñas de inimitable y exquisito gusto, y muy bien traídas, por cierto, que le valen justas y delirantes ovaciones. (Carthago Moderna, "La actualidad" b 8)

Las imprescindibles malagueñas que, a petición del público, canta siempre la citada artista, despertaron el entusiasmo del público. (El Popular, "Espectáculos" 2)

Su magistral interpretación de los cantes la hizo merecedora de apelativos como el de «reina del canto flamenco» (El Imparcial, "Correo" a 3) o «reina de las marianas, farrucas y garrotín gitano» (Heraldo de Zamora 2), aunque también fue denominada «reina del couplet» (Eco Artístico 9). Por su gran versatilidad, se movió como pez en el agua en la frontera entre ambos géneros, que en ocasiones quedó un poco difusa, como cuando en 1908 interpretó en el Salón Novedades de Alicante unos cuplés flamencos acompañada a la guitarra por el maestro Montoya: ${ }^{19}$

Amalia Molina [...] estuvo magistral, oyendo ovaciones delirantes del gentío inmenso que llenaba por completo el local, el cual se desbordaba de entusiasmo con los graciosísimos couplets flamencos de la mencionada coupletista. [...]

\footnotetext{
${ }^{16}$ Amalia Molina pasó todo el año 1909 y la primera mitad de 1910 de gira por Cuba y México.

${ }^{17}$ Durante su actuación en el Teatro Colón de Ciudad de México, en octubre de 1909, la acompañó el guitarrista José Aparicio (El Diario, "La metrópoli” 6); y en septiembre de 1910, se presentó en el Salón Novedades de Málaga junto al maestro Carlos Sánchez (El Popular, "Salón” 4).

18 «La Molina y la Cuba [sic] se completan de tal modo artísticamente que sería un buen acuerdo de ambas ir siempre juntas» (El Eco de Cartagena, “Amalia” 2).

${ }^{19}$ Unos meses antes, en el Salón de Actualidades de Cartagena, también había cantado «varios couplets de los más escogidos de su extenso repertorio», acompañada a la sonanta por Adela Cubas, «con esa maestría especial que solo posee tan aventajada concertista, formando entre las dos una verdadera notabilidad difícil de imitar por su original mérito» (Película 2).
} 
Enclaves. Revista de Literatura, Música y Artes Escénicas, n. ${ }^{\circ}$ 1, 2021, pp. 36-55. e-ISSN 2792-7350

Ángeles Cruzado Rodríguez, «La forja de una estrella. Configuración del

repertorio y la personalidad artística de Amalia Molina en la primera etapa del género de variedades», https://dx.doi.org/10.12795/enclaves.2021.i01.04

Ramón Montoya, maestro de guitarra, hizo su debut acompañando a la Amalia Molina en sus couplets. Este señor hace verdaderos prodigios, lo cual le valió una nutrida salva de aplausos. (Robelín 3)

Su dominio de los dos estilos también le permitió intercalar en los cuplés estrofas de coplas flamencas, a veces de manera improvisada. Encontramos un ejemplo de ello en enero de 1908, durante su actuación en el Salón de Actualidades de Cartagena:

[...] aprovechando que se encontraba entre el público el simpático matador de toros Rafael González (a) Machaquito, se sintió inspirada y cantó la siguiente copla:

Para jardines Valencia

la Habana para el tabaco,

para toreros valientes

ninguno como el «Machaco».

Al terminar el couplet donde intercaló la referida copla, le valió una entusiasta ovación por la oportunidad de la alusión. (El Eco de Cartagena, "Salón" 2)

Esa mezcla de géneros y estilos también quedó patente en números como el monólogo cómicolírico-bailable Caminito del cielo, compuesto para ella por el poeta malagueño José Sánchez Rodríguez, que le daba la oportunidad de lucirse cantando granaínas, marianas y tientos gitanos, además de mostrar sus buenas dotes para la actuación:

\section{AMALIA MOLINA, ACTRIZ}

Para completar el triunfo de la genial artista, faltábale presentarse bajo este nuevo aspecto, y el público, que no esperaba ciertamente tal conjunto de méritos en Amalia Molina, viose anoche gratamente sorprendido, con motivo de la interpretación del monólogo Caminito del cielo.

La obrita es un pretexto para que la famosa cupletista cante algunos números de su aplaudido repertorio, y fue desempeñada con notable acierto. (El Popular, "Espectáculos" c 4)

\subsection{Estrella coreográfica}

Aunque hasta el momento nos hemos centrado en su faceta de cantaora y cupletista, no hay que olvidar que desde niña Amalia Molina había cultivado el arte de Terpsícore, algo que continuaría haciendo durante toda su vida. En sus números cantados solía incluir pasos de baile y también el toque de castañuelas, que dominaba como una auténtica maestra. Por ejemplo, durante su estancia en Cartagena, los tangos, soleares y cuplés «los canta con un gusto singular y los adorna con su correspondiente parte de baile, donde se aprecia que no solamente es la primera hoy en España como cupletista, sino que también es difícil que nadie la aventaje como bailarina» (Fray-Cine, "Amalia" 2).

Multitud de referencias tomadas de las hemerotecas coinciden en destacar, por encima de todas, su faceta coreográfica. Pocos días después de su debut en el Salón de Actualidades de Madrid, ya había quien señalaba que la Molina era «sin duda alguna de las mejores bailarinas de España» (El Liberal, "Entre bastidores"b 4). Lo demostraba en los escenarios de variedades, donde además de ofrecer actuaciones individuales, con acompañamiento de guitarra u otro tipo de instrumentación, también formó parte de cuadros flamencos junto a grandes figuras del género. Por ejemplo, en 1905, en el Salón Zorrilla de Madrid, «bailó unas sevillanas y un tango con toda la gracia que haya en Serva la vari $[\mathrm{sic}] »$ (El País 3), junto a un elenco formado por las bailaoras Nicolasa González y la Paloma, y los cantaores Juanito Ríos, Luisa la de los Tangos y su admirado Antonio Chacón, acompañados a la guitarra por Miguel Borrull. 
Enclaves. Revista de Literatura, Música y Artes Escénicas, n. ${ }^{\circ}$ 1, 2021, pp. 36-55. e-ISSN 2792-7350

Ángeles Cruzado Rodríguez, «La forja de una estrella. Configuración del

repertorio y la personalidad artística de Amalia Molina en la primera etapa del género de variedades», https://dx.doi.org/10.12795/enclaves.2021.i01.04

Asimismo, fue contratada para actuar en fiestas organizadas por gentes de postín, deseosas de conocer el cante y el baile flamenco en su versión más auténtica, como la celebrada en 1907 en la Legación de México en Madrid:

[...] reunióse en el hermoso «hall» del hotel un cuadro completo del género formado por el famoso guitarrista Miguel Borrull, por el notable «cantaor» conocido por el «Mochuelo», las gentilísimas bailarinas hermanas Esmeraldas, y Amalia Molina, una de las «estrellas» del arte coreográfico andaluz.

[...] Sevillanas, tangos, peteneras, toda la gama de los géneros andaluz y flamenco, fue pasando ante los espectadores, sin que el cansancio rindiera los gentiles cuerpecitos de Amalia Molina y de las Esmeraldas (Monte-Cristo 2).

Por su formación clásica, junto a los maestros Pericet y Otero, la macarena rayaba a gran altura en las danzas de la Escuela Bolera, que en aquel tiempo aún compartían protagonismo con el baile flamenco en los escenarios. Con ese repertorio causó auténtica sensación en el Teatro Alcázar de México, donde cosechó excelentes críticas:

Si Amalia Molina se nos ha revelado como una coupletista de gran talento, y como una cantadora de flamenco que no tiene rival, más notable aún se nos ha revelado como bailarina, pues en el «baile inglés» no tiene igual; bailando boleros y malagueñas, ha alcanzado verdaderas y merecidas ovaciones, al grado de que la Molina es considerada hoy como superior bailando que cantando. (El Imparcial, "Correo" b 3)

Pero bailando hay que desengañarse, que donde está Amalia Molina, todo se nubla, todo se convierte en nada.

La bella sevillana ha causado una revolución en el Alcázar, con sus bailes, pues entusiasma tanta ligereza, tanto arte, tanta preciosidad en ademanes y figuras. Sus danzas nos parecen nuevas, y es que las [sic] imprime un sello especial que las hace seductoras. ¡Hay que ir a ver bailar a la encantadora Amalia Molina! (El Diario, "Correo" 6)

Ese afán de la artista por hacer del flamenco y el cuplé un espectáculo culto y refinado también se reflejaba en su concepción de la danza: «Su baile, no es el desgarrado de otras artistas, no es el flamenco exageradamente achulapado de otras, no; Amalia Molina, baila con elegante finura y artísticos movimientos que agradan sumamente a sus muchos admiradores» (Carthago Moderna, "La actualidad" a 9). Años más tarde, sería precisamente esa faceta coreográfica la que le abriría las puertas de los teatros europeos y la consagraría como estrella internacional, tras su triunfo al frente del ballet de la ópera Goyescas de Granados, que se estrenó en la Gran Ópera de París en diciembre de 1919. 
Enclaves. Revista de Literatura, Música y Artes Escénicas, n. ${ }^{\circ}$ 1, 2021, pp. 36-55. e-ISSN 2792-7350

Ángeles Cruzado Rodríguez, «La forja de una estrella. Configuración del repertorio y la personalidad artística de Amalia Molina en la primera etapa del género de variedades», https://dx.doi.org/10.12795/enclaves.2021.101.04

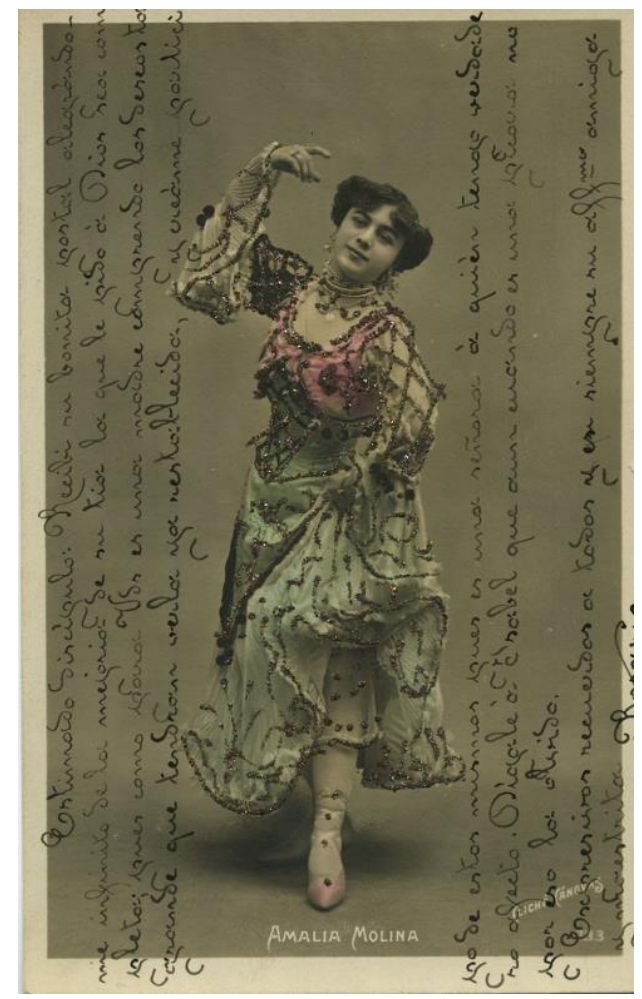

Imagen 2. Amalia Molina en una pose de baile. Centro Andaluz de Documentación del Flamenco.

\subsection{El género de los cantes y bailes regionales}

Las grandes inquietudes artísticas de la polifacética sevillana también la hicieron interesarse por los cantos y los bailes populares de las distintas regiones españolas, que poco a poco fue incorporando en su repertorio, y que terminaron convirtiéndose en un nuevo género, del que Amalia Molina puede considerarse creadora. En la primera década del siglo XX ya se ve el germen de esa especialidad, que en años posteriores alcanzó un gran desarrollo.

La primera referencia la encontramos en 1908, durante su actuación en el Palacio de la Ilusión de Salamanca, donde la artista, para agradecer al público su buena acogida, decidió obsequiarlo con «algunos cantos de esta tierra, que han sido dirigidos, en los ensayos, por el señor Bernal», y lo hizo ataviada con «un soberbio traje de charra» adquirido para la ocasión en la misma ciudad (El Adelanto, "Palacio" 2). En 1910, en el Teatro Pradera de Valladolid, «cantó, vestida con típicos trajes de charra, asturiana y andaluza, bellas canciones de los respectivos países» ( $A B C$, "Notas" 10); y poco después interpretó, en el Salón Pradera de Santander, «unas preciosas canciones asturianas, a las que sabe dar todo el intenso sentimiento, el inconfundible matiz, que requieren tan deleitosas baladas norteñas» (El Cantábrico, "Salón" 2).

En los años siguientes, aprovechando sus continuas giras por toda la geografía española, desarrolló un arduo trabajo de investigación en los pueblos, fiestas y romerías. Fue a buscar a los maestros más destacados de cada lugar, para estudiar in situ las canciones y las danzas populares, que luego interpretó en los escenarios convertidas en auténticas creaciones, pero sin perder su autenticidad: «Estudio las costumbres de cada pueblo y tomo de ellas lo más sano para llevarlo a la escena con el mejor arte posible», confesaba la artista (Diario de Burgos, "Salón" 2). 
Enclaves. Revista de Literatura, Música y Artes Escénicas, n. ${ }^{\circ}$ 1, 2021, pp. 36-55. e-ISSN 2792-7350

Ángeles Cruzado Rodríguez, «La forja de una estrella. Configuración del

repertorio y la personalidad artística de Amalia Molina en la primera etapa del género de variedades», https://dx.doi.org/10.12795/enclaves.2021.i01.04

Dentro de este nuevo género, inspirándose en el folclore regional, distintos compositores también fueron creando números exclusivos para ella, como las «Canciones asturianas» de Baldomero Fernández, los temas montañeses «Cantos de la tierruca» y «Peñas arriba» del maestro Pedro Vilches, "A Vizcaya» de Arocena y Alberdi, el cuplé «Ecos de Cantabria», la canción gallega «O gaiteriño» o la jota «Del vergel valenciano».

Asimismo, durante sus giras de los años 20 y 30 por América latina siguió ampliando el repertorio con la introducción de temas originarios de aquellas latitudes. Por mencionar solo algunos ejemplos, podemos citar el punto guajiro «Mi Cuba querida» y la canción criolla «Son oriental», ambas del cubano Eliseo Grenet; «El sombrero mexicano» y «La chiapaneca», del mexicano Juan Arozamena; o «El Tortillero» y «El rotito», del compositor chileno Osmán Pérez Freire. ${ }^{20}$

Puede afirmarse, por tanto, que Amalia Molina fue precursora de artistas como Antonia Mercé, la Argentina, que años más tarde también buscó inspiración en el folclore regional español, latinoamericano e incluso filipino para la creación de muchos de sus solos de danza, con música sinfónica compuesta para ella por autores como Turina, Valverde, Esplá o Pittaluga:

Al sobrevenir la decadencia del cuplé [...] se consolidó la soberanía de la canción española. [...] El charlestón no consiguió anular el interés de las jotas bravías de Aragón, de las serenatas de Valencia, del cante jondo de Andalucía, de las ternuras de Galicia, de la poesía que palpita cuanto brota de ambas Castillas [...].

Estas melodías populares, estilizadas, son las que en la actualidad sufren una nueva revisión y depuración, y sirven de temas a ilustres compositores para sus producciones, que aplaudimos en los grandes conciertos. Los cantos regionales conquistan mayor espacio estético, se hacen interpretar por las orquestas sinfónicas; pero el triunfo, entre los elementos culturales de hoy, se lo deben a las tonadilleras de ayer o a las que, como Amalia Molina [...], permanecen hoy fieles a la orientación españolísima. (Retana, "La estilización" 78)

\subsection{Escenografia de las varietés}

Además de todas las innovaciones y aportaciones mencionadas en lo que se refiere a la conformación de su repertorio, desde el inicio de su trayectoria como artista de variedades, Amalia Molina demostró una gran visión escénica. Si en 1904 llegaba a Madrid prácticamente con lo puesto, sus éxitos pronto le permitieron alcanzar una buena posición económica, y no dudó en invertir parte de las ganancias en la adquisición de vestuario y otros elementos escenográficos para presentar dignamente su arte. En 1908 ya llamaba la atención por la riqueza y variedad de su indumentaria:

La presentación de tan notable artista es la más lujosa que aquí hemos visto, puesto que sus trajes son de una riqueza extraordinaria y están confeccionados con un gusto exquisito, y creemos que ha de tener numeroso vestuario pues en las tres noches que viene actuando en tan favorecido salón, nos ha presentado tres completamente distintos, acompañados de una gran colección de mantones de Manila y capotes de paseo, siendo también la artista que mejor alhajada se presenta... (Fray-Cine, "Amalia" 2)

Su ajuar artístico se fue incrementando paulatinamente, al mismo ritmo que su selección de canciones y bailes, pues cada número contaba con vestuario, joyas y complementos específicos, adecuados a la temática o al personaje que interpretaba. Entre 1908 y 1910 estrenó un «traje de

\footnotetext{
${ }^{20}$ Amalia Molina impresionó algunas de estas canciones en Nueva York para la casa Columbia.
} 
Enclaves. Revista de Literatura, Música y Artes Escénicas, n. ${ }^{\circ}$ 1, 2021, pp. 36-55. e-ISSN 2792-7350

Ángeles Cruzado Rodríguez, «La forja de una estrella. Configuración del repertorio y la personalidad artística de Amalia Molina en la primera etapa del género de variedades», https://dx.doi.org/10.12795/enclaves.2021.i01.04

luces, un hermosísimo traje con taleguilla inclusive» (El Popular, "Espectáculos" a 4), un «clásico traje andaluz, de bota de cuero y calañés» (El Popular, "Espectáculos" b 4), «un lujosísimo traje confeccionado exprofeso [sic] en París» (La Patria 3); y sorprendió al público del Salón Pradera de Santander al presentarse «sobre unos zapatos Luis XV, dorados, de regio tacón», ataviada con «un traje de oro y sedas» (El Cantábrico, "Salón" 2). Mas sin duda una de las piezas más significativas de su vestimenta era su exquisita colección de mantones de Manila, que también fue creciendo con los años:

De todos los elementos que hacen atractivo y bello el arte delicado y sobrio de esa bailarina flamenca [...] uno de los primeros, más que su cuerpo esbelto y grácil, más que su voz infantil, quebrada a ratos, más que su tipo puro y castizo, y que sus ojos y su pelo negros como el ala del cuervo, más que la mayor parte de sus cantos y bailes, y tanto por lo menos como lo mejor de ellos, incluso que las divinas soleares gitanas que entona a veces lánguidas y melancólicas, extrañamente bellas, son sus mantones de Manila, de dibujos pomposos, colores brillantes y largos flecos.

Los mantones de Amalia Molina, ricos, variados, espléndidos, son un gran elemento estético. (El Noroeste, "Comentarios" 1)

La sevillana cuidaba al máximo todos los detalles. Los números inspirados en el folclore popular siempre trataba de llevarlos a escena con la mayor fidelidad al modelo original. Cuando viajaba a los pueblos y romerías para aprender los cantos y bailes regionales, aprovechaba para visitar museos o incluso acudía a familias de la zona en busca de los trajes más adecuados, y bien los adquiría in situ, bien encargaba su reproducción a una modista de confianza. ${ }^{21}$

\footnotetext{
${ }^{21}$ En la segunda mitad de los años 20, se puso en manos de modistos como Thiele o Retana, que crearon para ella un vestuario más moderno y sofisticado: «Amalia Molina se declara "cupletista de vanguardia", para arrancar al casticismo su propia médula. Antes vestía cada canción con el traje adecuado, que copiaba del Museo; ahora ha modernizado su arte y se declara "andaluza de vanguardia" y "usa trajes a capricho de orientación superrealista". [...] Lo que yo presento ahora -concluye- es creado para mí y con arreglo a mis indicaciones» (La Libertad 1).
} 
Enclaves. Revista de Literatura, Música y Artes Escénicas, n. ${ }^{\circ}$ 1, 2021, pp. 36-55. e-ISSN 2792-7350

Ángeles Cruzado Rodríguez, «La forja de una estrella. Configuración del repertorio y la personalidad artística de Amalia Molina en la primera etapa del género de variedades», https://dx.doi.org/10.12795/enclaves.2021.101.04

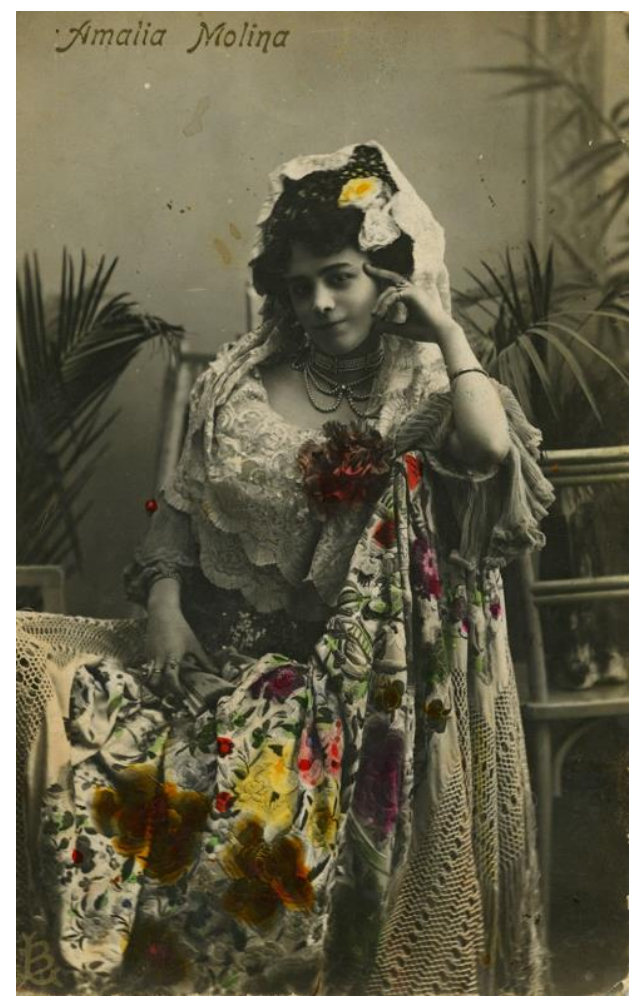

Imagen 3. Amalia Molina luciendo una de sus ricas toilettes.

Centro Andaluz de Documentación del Flamenco.

Otro elemento fundamental de su puesta en escena eran los telones forillo que mostraban lugares emblemáticos de la geografía española y que servían para crear la ambientación adecuada. Contaba con uno específico para cada número, algo en lo que también puede considerarse pionera. La primera referencia periodística que encontramos sobre ellos es de 1911 y da cuenta del estreno en el Teatro Liceo de Salamanca de «una decoración que representa la perspectiva de la plaza desde el arco de San Martín» (El Adelanto, "Teatro" 3). Era obra del prestigioso pintor Luis Muriel, que fue su escenógrafo de cabecera hasta su fallecimiento, en $1919 .^{22}$ En 1916 había acumulado ya un total de cuarenta y cinco:

Todos sirven de fondo a una riquísima y suntuosa decoración de puro estilo árabe, adornada con hermosos cortinajes de damasco de seda y alfombras que imitan el mosaico árabe.

El telón de boca es serio y figura dos cortinones que se descorren. En el centro aparece el escudo de España.

Cuando Amalia termina un número, no se baja el telón, sino que se apaga la luz mientras los maquinistas realizan la mutación.

Entre tanto, la orquesta preludia la canción que luego ha de salir a cantar.

Puede asegurarse que en el género de varietés no hay nadie que se presente con tanto lujo y conciencia artística en trajes y decorado. (García Carraffa 97-98)

\footnotetext{
${ }^{22}$ Después trabajó con pintores de la categoría de Ignacio Zuloaga y Joaquín Sorolla.
} 
Enclaves. Revista de Literatura, Música y Artes Escénicas, n. ${ }^{\circ}$ 1, 2021, pp. 36-55. e-ISSN 2792-7350

Ángeles Cruzado Rodríguez, «La forja de una estrella. Configuración del repertorio y la personalidad artística de Amalia Molina en la primera etapa del género de variedades», https://dx.doi.org/10.12795/enclaves.2021.i01.04

El lujo, elegancia y exquisitez que caracterizaban su vestuario y su puesta en escena se convirtieron en uno de sus signos distintivos, y ejercían sobre el público un poder de atracción casi tan fuerte como el de su arte:

La aparición de esta mujercita delgada produce asombro. Es una aparición luminosa. Su traje refulge al sentir la caricia de la luz. Sus dedos, sus orejas, su garganta, sus muñecas aparecen aherrojados por hermosas joyas de cambiantes deliciosos...

-iQué bien se presenta!...

Esto dicen todas las bocas y efectivamente es verdad. Se presenta muy bien. (Luengo y Conde 1)

Ese refinamiento, tanto de los cuplés y los bailes como del envoltorio en que los ofrecía, resultó esencial para cambiar la concepción que muchos tenían del género de variedades, y atraer a los teatros a una audiencia más amplia y plural, a «ese público que gusta de los espectáculos cultos y que sabe apreciar el verdadero arte» (Las Provincias 2). Por tanto, podemos afirmar que Amalia Molina se adelantó a Aurora Jauffret, a quien Álvaro Retana considera «dignificadora de las variedades» porque, tras su debut en el Trianón Palace en junio de 1911, «acabó de barrer, con su arte depurado y sus iniciativas inteligentes, cuanto de feo y ordinario quedaba en el género ínfimo» ("Historia" 44). ${ }^{23}$

Antes de la aparición de La Goya, la Molina ya era «una de las pocas artistas del género que cultivan un repertorio perfectamente moral y de buen gusto» (El Adelanto, "Amalia" 2), «la artista predilecta del público fino, [...] por su trabajo cultísimo y delicado, la artista de las señoras... y esto sí que es conseguir en ese género llamado de Varietés» (Las Provincias 2). De hecho, nada sucedió por casualidad, pues en 1908, en una entrevista concedida durante su actuación en La Coruña, la propia artista reconocía su voluntad de captar a la audiencia femenina:

Amalia Molina préciase de gustar a las damas. Yo creo que gusta más a los hombres. Pero ella lo acaba de explicar.

- Los espectáculos para hombres han decaído. Hay que buscar a las señoras. (El Noroeste, "Amalia" 1)

\section{Las claves de su éxito}

En esos pocos años de su carrera que hemos tomado como referencia, y que se corresponden con sus inicios en el género de variedades, se distinguen ya claramente las que serían las líneas fundamentales de su propuesta artística, que siguió desarrollando durante toda su vida. Por su versatilidad, y por la variedad de estilos que cultivó, Amalia Molina es una artista difícil de clasificar en un género concreto. Era cupletista, pero no siguió la línea sicalíptica imperante en los albores del siglo XX, sino que desarrolló un nuevo tipo de canción andaluza en la que primaban la gracia y el sentimiento. Era cantaora y bailaora, mas se alejó del estereotipo del denostado flamenquismo, y emprendió una labor de refinamiento y dignificación del arte jondo como espectáculo teatral. Inició, además, una tarea de recuperación de los cantos y bailes del

\footnotetext{
${ }^{23}$ "A "La Goya" fue a la primera que se le ocurrió ataviarse para cada canción con la indumentaria adecuada y lanzó el primer repertorio para familias, que le había de conquistar las simpatías de los hogares. Fue la primera cupletista para personas decentes, y su recato personal, la meditación de su trabajo y sus constantes anhelos de superación estimularon a sus compañeras demostrando al mundo que el arte frívolo podía ser compatible con otras modalidades escénicas consideradas como de mayor categoría» (Retana, "El arte” 15).
} 
Enclaves. Revista de Literatura, Música y Artes Escénicas, n. ${ }^{\circ}$ 1, 2021, pp. 36-55. e-ISSN 2792-7350

Ángeles Cruzado Rodríguez, «La forja de una estrella. Configuración del

repertorio y la personalidad artística de Amalia Molina en la primera etapa del género de variedades», https://dx.doi.org/10.12795/enclaves.2021.i01.04

folclore regional español para llevarlos a escena sin menoscabo de su autenticidad. A todo ello hay que sumar las distintas combinaciones y mezclas posibles, como los cuplés con acompañamiento de guitarra, la orquestación del cante flamenco o las canciones de autor inspiradas en los aires andaluces y de otras regiones españolas e incluso latinoamericanas. Ante la necesidad de hallar un término que englobe todas las manifestaciones de su arte, en 1910 hay quien la definía como «cantatriz andaluza» $(A B C$, "Notas" 11) o, de modo más global, «cantatriz española»:

Puede decirse que es artista única en su género. No la cupletista de café concert; no la cantaora de tablado. Es lo más puramente artístico de ello, y algo más, que solo es ella. Cantatriz española es la denominación que para su arte se ha empleado más, y no encontraríamos otra más adecuada. Toda el alma española derramada en las canciones típicas, en las canciones que son sangre y savia de la raza, está expresada por la bella artista, que ha sabido asimilarla y exteriorizarla con toda la suya, delicada y genial. (El Cantábrico, "Amalia” 2)

Independientemente del nombre que se le quiera atribuir, distintas fuentes coinciden en designar a Amalia Molina como la «creadora de un género personal e inimitable» ( $L a$ Correspondencia de España 5), como «la perla de las artistas de su género, en el que difícilmente habrá otra que sea tan completa, tan graciosa y tan artista» (El Cantábrico, "Teatros" 2):

— ¿Por qué triunfa siempre Amalia Molina? [...]

- Porque es artista.

Hubo un tiempo en que para dedicarse al género de varietés creyeron muchos que solo se necesitaba ser bella..., tener buen tipo..., alguien que las patrocinase, y desfilaron por los escenarios multitud de jóvenes a buscar aplausos y dinero.

Pero la realidad en el arte, como en todas las cosas, se impone, y esas figuras que pretendieron encumbrarse tan solo por su físico, se acabaron pronto, más pronto de lo que ellas quisieran.

Por eso la figura grácil de Amalia Molina, fina de cuerpo, se agranda en escena como los genios, hasta el punto de que el espectador no puede caer en la cuenta de su menudita personilla, que se va agigantando por los sublimes resortes del arte. (Diario de Burgos, "Amalia" 2)

Si desde el principio dio buena muestra de sus muchas capacidades artísticas, también dejó entrever una personalidad bien definida, a la que siempre se mantendría fiel. Era una artista creadora, sumamente original, con sello propio, lo cual sin duda constituyó una de las claves fundamentales de su éxito. La propia Amalia era consciente de ello, pues, al ser preguntada por el secreto o fórmula de su arte, no dudó en responder que «para triunfar es necesario crear» (Duncan 9).

\section{Referencias}

$A B C$. "La fiesta del martes en nuestra casa." 289 (26 Oct. 1905): 13-14. Web 30 Oct. 2020. $A B C$. "Notas teatrales." 1.977 (7 Nov. 1910): 11. Web 30 Oct. 2020.

$A B C$. "Notas teatrales." 2.010 (10 Dic. 1910): 10. Web 30 Oct. 2020.

Blas Vega, José. Los cafés cantantes de Sevilla. Madrid: Cinterco, 1987.

Carthago Moderna. "La actualidad en los cines." 15 (12 Ene. 1908): 8-9. Web 30 Oct. 2020.

Carthago Moderna. "La actualidad en los cines." 16 (19 Ene. 1908): 8-9. Web 30 Oct. 2020. 
Enclaves. Revista de Literatura, Música y Artes Escénicas, n. . 1, 2021, pp. 36-55. e-ISSN 2792-7350

Ángeles Cruzado Rodríguez, «La forja de una estrella. Configuración del

repertorio y la personalidad artística de Amalia Molina en la primera etapa del género de variedades», https://dx.doi.org/10.12795/enclaves.2021.i01.04

Carretero Novillo, José María [El Caballero Audaz]. "La artista de la Macarena." Nuevo Mundo 1.211 (23 Mar. 1917): 16-17. Web 31 Oct. 2020.

Cavia Naya, Victoria. "Mujeres, teatro, música y variedades: de las boleras y flamencas a las bailarinas de danza española (1885-1927)." Cuadernos de Música Iberoamericana. 25-26 (Oct.-Dic. 2013): 51-73. https://revistas.ucm.es/index.php/CMIB/article/view/58948 Web 20 Oct. 2020.

Colirón. "Información teatral." Madrid Cómico 142 (17 Nov. 1912): 12. Web 31 Oct. 2020.

Cruces Roldán, Cristina. "El flamenco." Expresiones culturales andaluzas. Coordinado por Isidoro Moreno y Juan Agudo. Sevilla: Aconcagua Libros, 2012. 219-281.

https://dialnet.unirioja.es/servlet/articulo?codigo=4096948 Web 30 Oct. 2020.

Cruzado Rodríguez, Ángeles. Amalia Molina (1885-1956). Memoria de una universal artista sevillana. Sevilla: Benilde, 2020.

Cuevas, E. “Amalia Molina.” El Cantábrico 5.651 (10 Dic. 1910): 2. Web 30 Oct. 2020.

Diario de Burgos. "Salón Parisiana." 7.563 (3 Feb. 1916): 2. Web 30 Oct. 2020.

Diario de Burgos. "Amalia Molina." 7.565 (5 Feb. 1916): 2. Web 30 Oct. 2020.

Duncan, Edith. "Un rato de charla con la triunfadora artista Amalia Molina." Diario de la Marina 200 (20 Jul. 1927): 8-12. Web 30 Oct. 2020.

Eco Artístico. "Valladolid." 38 (25 Nov. 1910): 9. Web 30 Oct. 2020.

El Adelanto. “¡Nos vamos a divertir!” 7.496 (24 Nov. 1908): 1. Web 30 Oct. 2020.

El Adelanto. "Palacio de la Ilusión." 7.500 (28 Nov. 1908): 2. Web 30 Oct. 2020.

El Adelanto. "Amalia Molina." 8.142 (5 Ene. 1911): 2. Web 30 Oct. 2020.

El Adelanto. "Teatro del Liceo." 8.148 (12 Ene. 1911): 3. Web 30 Oct. 2020.

El Cantábrico. "Amalia Molina." 5.645 (4 Dic. 1910): 2. Web 30 Oct. 2020.

El Cantábrico. "Amalia Molina." 5.649 (8 Dic. 1910): 1. Web 30 Oct. 2020.

El Cantábrico. "Salón Pradera." 5.661 (20 Dic. 1910): 2. Web 30 Oct. 2020.

El Cantábrico. "Teatros y salones." 5.671 (31 Dic. 1910): 2. Web 30 Oct. 2020.

El Día. "Espectáculos." 8.328 (1 Jun. 1904): 2. Web 30 Oct. 2020.

El Diario. "Correo de teatros." 1.022 (16 Ago. 1909): 2. Web 30 Oct. 2020.

El Diario. "La metrópoli se divierte." 1.093 (25 Oct. 1909): 6. Web 30 Oct. 2020.

El Diario. "[anuncio] Agencia de Fonógrafos." (16 Sep. 1910): 22. Web 30 Oct. 2020.

El Eco de Cartagena. "Salón de Actualidades." 13.840 (11 Ene. 1908): 2. Web 30 Oct. 2020.

El Eco de Cartagena. "Amalia Molina." 13.858 (3 Feb. 1908): 2. Web 30 Oct. 2020.

El Imparcial. "Correo de teatros." 4.687 (19 Jul. 1909): 3. Web 30 Oct. 2020.

El Imparcial. "Correo de teatros." 4.714 (15 Ago. 1909): 3. Web 30 Oct. 2020.

El Liberal. "Entre bastidores." 6.533 (6 Mar. 1895): 4. Web 30 Oct. 2020.

El Liberal. "Entre bastidores." 8.987 (23 May. 1904): 4. Web 30 Oct. 2020.

El Noroeste. "Amalia Molina." 4.821 (10 Dic. 1908): 1. Web 30 Oct. 2020.

El Noroeste. "Comentarios." 4.824 (13 Dic. 1908): 1. Web 30 Oct. 2020.

El País. "De teatros." 6.701 (10 Dic. 1905): 3. Web 30 Oct. 2020.

El Popular. "Espectáculos públicos." 1.739 (18 Ago. 1908): 4. Web 30 Oct. 2020.

El Popular. "Espectáculos públicos." 1.745 (24 Ago. 1908): 2. Web 30 Oct. 2020.

El Popular. "Espectáculos públicos." 1.750 (29 Ago. 1908): 4. Web 30 Oct. 2020.

El Popular. "Salón Novedades." 2.485 (4 Sep. 1910): 4. Web 30 Oct. 2020.

El Popular. "Espectáculos públicos.” 1.766 (14 Sep. 1908): 1. Web 30 Oct. 2020.

El Popular. "Espectáculos públicos.” 1.772 (20 Sep. 1908): 4. Web 30 Oct. 2020.

El Teatro. "Amalia Molina." 47 (Ago. 1904): 5-8.

Fray-Cine. "Amalia Molina.” El Eco de Cartagena 13.836 (7 Ene. 1908): 2. Web 30 Oct. 2020. 
Enclaves. Revista de Literatura, Música y Artes Escénicas, n. . 1, 2021, pp. 36-55. e-ISSN 2792-7350

Ángeles Cruzado Rodríguez, «La forja de una estrella. Configuración del

repertorio y la personalidad artística de Amalia Molina en la primera etapa del género de variedades», https://dx.doi.org/10.12795/enclaves.2021.i01.04

Fray-Cine. "Por los cines." El Eco de Cartagena 13.851 (25 Ene. 1908): 2. Web 30 Oct. 2020. Fray-Cirilo. "Teatro." La Rioja 1.934 (7 Jun. 1895): 2. Web 30 Oct. 2020.

Fray-Cirilo. "Teatro." La Rioja 1.935 (8 Jun. 1895): 2. Web 30 Oct. 2020.

García Carraffa, Arturo. Cancionistas y bailarinas españolas. Amalia Molina. Madrid: Sáez Hermanos y Compañía, 1916.

Gómez Bajuelo, Gil. "La vida y el arte de la gran 'estrella' sevillana Amalia Molina.” $A B C$ de Sevilla 12.762 (7 Jul. 1944): 4. Web 31 Oct. 2020.

Heraldo de Zamora. "Noticias generales." 4.103 (7 Ene. 1911): 2. Web 30 Oct. 2020.

La Correspondencia de España. "Los teatros." 19.176 (13 Ago. 1910): 5. Web 30 Oct. 2020.

La Libertad. "Pandereta." 2.927 (6 Ago. 1929): 1. Web 30 Oct. 2020.

La Opinión. "Teatros y artistas." 1.880 (9 Jul. 1910): 2. Web 30 Oct. 2020.

La Patria. "Espectáculos." 9.641 (16 Abr. 1910): 3. Web 30 Oct. 2020.

Larios de Medrano, J. “Se 'hacen' cupletistas a 64 pesetas...” El Liberal 13.647 (27 Mar. 1917): 1-2. Web 31 Oct. 2020.

Las Provincias. "La Exposición Nacional de Valencia." 16.077 (24 Sep. 1910): 2. Web 30 Oct. 2020.

Luengo y Conde, Jesús. “Amalia Molina.” El Progreso 100 (13 Dic. 1908): 1-2. Web 30 Oct. 2020.

Luna López, Inés María. La soledad como categoría estética: Correspondencias simbólicas entre copla flamenca y canción española. Tesis doctoral Universidad de Sevilla, 2017. https://idus.us.es/handle/11441/70886 Web 20 Oct. 2020.

Monte-Cristo. "En la Legación de Méjico.” El Imparcial 14.360 (13 Mar. 1907): 2. Web 30 Oct. 2020.

Muñoz San Román, José. "Los 'Cuadros flamencos' y el veterano maestro Otero." $A B C$ de Sevilla 8.474 (22 Feb. 1930): 5-6. Web 31 Oct. 2020.

Película. "Por los cines." El Eco de Cartagena 13.855 (30 Ene. 1908): 2. Web 30 Oct. 2020.

R. M. "La copla de hoy." La Correspondencia Militar 7.290 (24 Dic. 1901): 1. Web 31 Oct. 2020.

Retana, Álvaro [Carlos Fortuny]. "La novela de una sevillana." El Heraldo de Madrid 13.572 (29 Jul. 1929): 8-9. Web 31 Oct. 2020.

Retana, Álvaro [Carlos Fortuny]. "La estilización de los cantos regionales." Blanco y Negro 2.086 (10 May. 1931): 73-78. Web 31 Oct. 2020.

Retana, Álvaro [Carlos Fortuny]. "Historia de las 'varietés'.” Estampa 235 (9 Jul. 1932): 4344. Web 31 Oct. 2020.

Retana, Álvaro [Carlos Fortuny]. "El arte frívolo en España." Ahora 1.533 (24 Nov. 1935): 15 18. Web 31 Oct. 2020.

Robelín, Heraldo de Alicante. "Salón Novedades." 973 (9 Jun. 1908): 3. Web 30 Oct. 2020.

Salaün, Serge. "El género ínfimo: mini-culture des masses." Bulletin Hispanique, n. ${ }^{\circ}$ 90.1, 1989, pp. 147-167. https://www.persee.fr/doc/hispa_0007-4640_1989_num_91_1_4667 Web 20 Oct. 2020.

Salaün, Serge. El cuplé (1900-1936). Madrid: Espasa-Calpe, 1990.

Salaün, Serge. "Las mujeres en los escenarios españoles (1890-1936). Estrellas, heroínas y víctimas sin saberlo." Dossiers feministes, n. ${ }^{\circ} 10,2007$, pp. 63-83.

https://www.raco.cat/index.php/DossiersFeministes/article/view/102540. Web 20 Oct. 2020.

Salaün, Serge y Claire-Nicole Robin. “Artes y espectáculos: tradición y renovación.” 1900 en España. Edición de Serge Salaün y Carlos Serrano. Madrid: Espasa-Calpe, 1991. 